\title{
SUPERVISI AKADEMIK KEPALA SEKOLAH DAN DISIPLIN KERJA GURU TERHADAP PRODUKTIVITAS KERJA GURU SD NEGERI SE KECAMATAN MUMBULSARI JEMBER
}

\author{
Oleh: \\ Sulistyaningsih \\ UIN Maliki Malang \\ sulistyaningsihspd54@gmail.com
}

\begin{abstract}
:
This study aims to determine the influence/contribution of school headmasters' academic supervision and teacher work discipline on the work productivity of state elementary school teachers in Mumbulsari District, Jember Regency. This is a quantitative survey research with the number of sample is 148 peoples. Data collection tool is questionnaire with regression techniques for data analysis. The results of this study show that: (1) There is a positive and significant influence between the school headmasters' academic supervision on the teachers' work productivity in state elementary schools in Mumbulsari District, Jember Regency. (2) There is a positive and significant influence between teachers' work discipline on teachers' work productivity of state elementary schools in Mumbulsari District, Jember Regency. (3) There is a positive and significant influence simultaneously on the school headmasters' academic supervision and teacher work discipline on the work productivity of public elementary school teachers in Mumbulsari District, Jember Regency at $59.1 \%$, while as many as $40.9 \%$ are influenced by factors other than the headmasters' academic supervision and teacher work discipline. Thus, both of these variables can be used as predictors of the trend of increasing work productivity of public elementary school teachers in Mumbulsari District, Jember Regency.
\end{abstract}

Keywords: Supervise Akademik Kepala Sekolah, Disiplin Kerja Guru, Produktivitas Kerja Guru

\section{A. Pendahuluan}

Pendidikan merupakan inti kemajuan suatu bangsa. Kualitas Sumber Daya Manusia (SDM) secara umum ditentukan oleh mutu pendidikan bangsa tersebut. ${ }^{1}$ Untuk menyongsong era globalisasi yang

${ }^{1}$ Mulyasa, Uji Kompetensi dan Penilaian Kinerja Guru, (Bandung: PT Remaja Rosdakarya, 2013), hlm. 15. 
sedang dimasuki saat ini maka pembangunan pendidikan harus dijadikan prioritas utama dalam menghadapi masa depan bangsa. Hal ini perlu lebih ditekankan agar kita mampu memasuki era globalisasi dengan penuh harapan dan kepastian, dimana Indonesia memiliki sumber daya manusia yang berkualitas sebagai hasil dari pendidikan yang berkualitas, yang dipandu oleh guru yang bermutu dan produktif.

Berdasarkan laporan UNDP PBB pada tanggal 21 Maret 2017, IPM (Indeks Pembangunan Manusia)/HDI (Human Development Index), Indonesia berada pada peringkat ke-113 dari 187 negara pada tahun 2015. Sebelumnya peringkat HDI untuk Indonesia pada tahun 2014 adalah ke-110. Dinamika pada komponen HDI Indonesia antara tahun 2014-2015 di bidang pendidikan yang terlihat yaitu jumlah murid yang dikeluarkan dari sekolah (drop out) naik dari 11\% menjadi $18,1 \%$,sementara untuk kesenjangan pendidikan tetap sebesar $20,8 \%{ }^{2}$

Data tersebut menunjukkan bahwa tantangan besar bangsa Indonesia adalah peningkatan kualitas SDM melalui pendidikan yang bermutu. Dalam rangka menghasilkan sumber daya manusia yang berkualitas dan berkarakter yang mampu bersaing dengan negara maju maka sangat diperlukan guru yang berkualitas dan produktif.

Dalam proses pembelajaran guru merupakan pemegang utama, karena secara teknis guru dapat menterjemahkan proses perbaikan dalam system pendidikan di dalam satu kegiatan di kelasnya. Guru wajib mengembangkan dan memanfaatkan kemampuan profesionalnya sehingga dapat meningkatkan produktivitas kerja dalam melaksakan tugas dan fungsinya, karena pendidikan yang berkualitas membutuhkan pendidik yang berkualitas pula. Dari sini dapat dikatakan bahwa program pendidikan di SD Negeri Kecamatan Mumbulsari, akan lebih berarti jika didukung oleh tenaga pendidik yang memiliki kemampuan professional dengan kinerja yang produktif.

Guru yang profesional dan produktif dibangun melalui penguasaan sejumlah kompetensi yang nyata diperlukan untuk mendukung pelaksanaan tugas pekerjaannya. Mulyasa menjelaskan bahwa guru professional dituntut untuk memiliki penguasaan isi bidang studi, pemahaman karakteristik peserta didik, melakukan pembelajaran yang mendidik, serta potensi pengembangan profesionalisme dan kepribadian. ${ }^{3}$

\footnotetext{
2 UNDP, Laporan Peringkat HDI Indonesia terbaru 2016, http//www.kompasiana.com, 21 Maret 2017, diakses tanggal 5 Mei 2017.

${ }^{3}$ Mulyasa, UjiKompetensidanPenilaianKinerja Guru, (Bandung: PT Remaja Rosdakarya, 2013), hlm.6.
} 
Guru dalam melaksanakan tugasnya perlu mengembangkan potensinya secara terus menerus, mampu menempatkan diri sesuai jabatan, dan memiliki kepribadian yang mendukung pelaksanaan tuganya, sehingga proses keberhasilan pendidikan di sebuah lembaga didukung oleh guru yang memiliki produktivitas yang tinggi.

Produktivitas kerja guru merupakan faktor yang sangat menentukan keberhasilan pendidikan dalam sebuah lembaga pendidikan. Oleh karena itu pengembangan guru dan pengukuran produktivitas kerjanya sangatlah penting. Penilaian dan pengukuran produktivitas kerja meliputi penilaian terhadap perencanaan dan pelaksanaan proses proses pembelajaran, prestasi akademik, karya pengembangan profesi, serta keikutsertaan dalam forumi lmiah. ${ }^{4}$

Produktivitas kerja guru mencakup sikap mental dan perilaku guru yang selalu mempunyai pandangan bahwa pekerjaan yang dilaksanakan hari ini harus lebih baik/lebih berkualitas dibandingkan pekerjaan kemarin, dan pekerjaan pada saat yang akan datang harus lebih baik daripada pekerjaan hari ini. ${ }^{5}$ Produktivitas kerja yang dimaksud di sini merupakan kemampuan seseorang untuk menggunakan kekuatannya dan mewujudkan segenap potensi yang ada padanya guna mewujudkan kreativitas. Peningkatan produktivitas kerja pada diri seseorang akan berdampak pada prestasi kerja sehingga pada akhirnya keberhasilan sebuah pendidikan akan tercapai. Hal ini sesuai dengan pendapat Susanto yang menyatakan bahwa peningkatan produktivitas kerja seseorang akan berdampak terhadap peningkatan motivasi kerja dan keinginan untuk berprestasi. $^{6}$ Hal senada juga disampaikan oleh Nitisemito bahwa produktivitas kerja guru yang rendah akan berdampak terhadap rendahnya semangat kerja dan meningkatnya tingkat absensi. ${ }^{7}$

Sedarmayanti ${ }^{8}$ mengatakan bahwa tinggi rendahnya produktivitas kerja ternyata dipengaruhi oleh banyak faktor, mulai dari sikap mental (motivasi kerja, disiplin kerja, etika kerja), pendidikan, keterampilan,

${ }^{4}$ Tri AtmadjiSutikno,Indikator Produktivitas Kerja Gurun Sekolah Menengah Kejujuran, VOL. 32, NO. 1, Februari 2009: 107-118

5Sinungan, Produktivitas Apa dan Bagaimana, (Jakarta: Bumi Aksara, 2009), hlm. 16

${ }^{6}$ Ahmad Susanto, Manajemen Peningkatan Kinerja Guru, (Jakarta: Prenadamedia Group, 2016), hlm. 106.

${ }^{7}$ Dwi Agug Nugroho Arianto, Analisis Penyebab Dampak Rendahnya Semangat Kerja Guru, Jurnal Dinamika Ekonomi dan Bisnis, Vol 11 No. 1 Maret 2014.

${ }^{8}$ Sedarmayanti, Sumber Daya Manusia dan Produktivitas Kerja, (Bandung: Mandar Maju, 2009), hlm. 71. 
manajemen, tingkat penghasilan, gizi dan kesehatan, lingkungan dan iklim kerja, sarana prasarana serta teknologi.

Dari beberapa faktor yang dipaparkan di atas, terdapat sikap mental berupa disiplin yang berpengaruh terhadap produktivitas kerja, dimana pengaruh tersebut menunjukkan hubungan sebab akibat. Sebagaimana dikatakan Susanto ${ }^{9}$ bahwa dengan adanya disiplin kerja yang baik dari kepala sekolah maupun stafnya (guru), maka produktivitas kerja yang dihasilkannya pun akan meningkat, sehingga tujuan pendidikan yang dicita-citakan oleh sekolah akan tercapai. Disiplin kerja merupkan hal yang harus ditanamkan dalam diri setiap guru karena hal ini akan menyangkut tanggungjawab moral pada tugas dan kewajibannya. Seperti juga suatu tingkah laku yang bisa dibentuk melalui kebiasaan.

Disiplin adalah sikap kesediaan dan kerelaan untuk mematuhi dan menaati segala norma peraturan yang berlaku di organisasi. Disiplin pegawai yang baik akan mempercepat pencapaian tujuan organisasi, sedangkan disiplin yang merosot akan menjadi penghalang dan memperlambat pencapaian tujuan organisasi. ${ }^{10}$ Jadi bisa dikatakan bahwa dalam sebuah lembaga pendidikan, kedisiplinan merupakan kunci keberhasilan dalam mencapai visi dan misi lembaga tersebut.

Sedarmayanti mengatakan bahwa disiplin kerja merupakan salah satu faktor dominan yang mempengaruhi produktivitas kerja. Hal ini dibuktikan oleh penelitian yang dilakukan oleh Nur Wahyu yang menyatakan bahwa disiplin kerja mempunyai pengaruh yang positif dan signifikan sebesar $97,40 \%$ terhadap produktivitas kerja. ${ }^{11}$

Penelitian lain terkait pengaruh disiplin kerja terhadap produktivitas kerja guru juga dilakukan oleh beberapa peneliti, diataranya Heru Widodo ${ }^{12}$, Sri Utami ${ }^{13}$, Sri Sugiyarti, Alwi Suddin, Ernawati ${ }^{14}$, dan

${ }^{9}$ Ahmad Susanto, Manajemen Peningkatan Kinerja Guru, (Jakarta: Prenadamedia Group, 2016), hlm. 115.

${ }^{10}$ EdySutrisno, ManajemenSumberdayaManusia, (Jakarta: Prenamedia Group, 2016), hlm. 96.

${ }^{11}$ NurWahyuHidayati, JurnalPendidikanEkonomi, Vol. 2 No. 4, 2013

${ }^{12}$ Heru Widodo, Pengaruh Kompetensi Profesional, Lingkungan Kerja, Disiplin dan Diklat terhadap Produktivitas Guru, (e-jurnal STIE-AUB), 2016.

${ }^{13}$ Sri Utami, Hubungan antara Lingkungan Kerja dan Disiplin Kerja dengan produktivitas kerja Guru SMP Negeri Tenggarong, (E-Jurnal Unikarta Cemerlang), 2009.

${ }^{14}$ Sri Sugiarti, Alwi Suddin, Ernawati, Pengaruh Kepemimpinan, Disiplin dan Kompetensi terhadap Poduktivitas Kerja Guru dengan Loyalitas sebagai variabel Media pada SMP Negeri 4 Surakarta, (e-jurnal Unisri, Vol. 10 No. 1), 2016.

$270 \mid$ JURNAL LISAN AL-HAL 
Heri Prihatin ${ }^{15}$, dengan hasil penelitian bahwa disiplin kerja berpengaruh positif terhadap produktivitas kerja guru.

Selain disiplin kerja, faktor lain yang juga berpengaruh terhadap peningkatan produktivitas kerja guru adalah supervisi akademik yang dilakukan kepala sekolah. Pelaksanaan supervisi dapat menjadi bagian dalam upaya meningkatkan produktivitas kerja guru. Glickman sebagaimana dikutip Saiful Sagala menyebutkan bahwa supervisi pengajaran yang selanjutnya dikenal dengan sebutan supervisi akademik adalah upaya yang dilakukan untuk membantu guru agar mau terus belajar untuk meningkatkan kualitas pembelajarannya. ${ }^{16}$

Supervisi akademik merupakan salah satu aspek penting dilakukan oleh kepala sekolah dalam meningkatkan kualitas pembelajaran. Guru yang profesional akan selalu berusaha untuk meningkatkan kualitas pembelajaran dengan bantuan dari kepala sekolah. Hal ini membuktikan bahwa peningkatan kualitas pembelajaran tidak hanya ditentukan oleh diri guru sendiri, tetapi harus diupayakan bersama antara guru dan supervisor. Sehingga pada akhirnya akan tercipta guru yang profesional dan memiliki produktivitas yang tinggi. ${ }^{17}$ Dengan demikian dapat dikatakan bahwa supervisi akademik yang dilakukan oleh kepala sekolah mempengaruhi produktivitas kerja guru.

Pernyataan tersebut di atas diperkuat oleh penelitian yang dilakukan oleh Widi Yuliani, ${ }^{18}$ Bella Ghia Dimmera, Asrori, Wahyudi, ${ }^{19}$ Sutama, ${ }^{20}$ dengan hasil penelitian bahwa supervisi akademik kepala sekolah berpengaruh positif dan signifikan terhadap produktivitas kerja guru.

\footnotetext{
${ }^{15}$ Heri Prihatin, Pengaruh Tingkat Pendidikan Guru dan kedisiplinan Kerja terhadap produktivitas Kerja Guru MTs Negeri Nguntoronadi Kabupaten Wonogiri, (Tesis IAIN Surakarta), 2014.

${ }^{16}$ Saiful Sagala, Supervisi Pembelajaran, (Bandung: Alfabeta, 2010), hlm. 91

${ }^{17}$ I Wayan arnasa, Nyoman Natajaya, I Gusti Ketut Arya Sunu, Kontribusi Kompetensi Guru, Etos Kerja Guru, Budaya Organisasi, dan Supervisi terhadap Produktivitas Kerja Guru di Sekolah Regant School Denpasar, Uurnal Program Sarjana Universitas Pendidikan Ganesha, Volume 5), 2014.

${ }^{18}$ Widi Yuiani, Pengaruh Kualitas Kerja, Pengawasan Kerja dan Kedisiplinan terhadap Pduktivitas kerja, (Jurnal Ekonomi Volume 9 No. 2), 2011.

${ }^{19}$ Bella Ghia Dimmera, Asrori, Wahyudi, Pengaruh Supervisi Akademik Kepala sekolah dan Kompetensi Profesional Guru terhadap Produktivitas kerja, Uurnal Pendidikan dan pembelajaran, Vol. 5 No. 2), 2016.

${ }^{20}$ Prof Sutama, Keson, Bajur, Peran Kompetensi Kepala Sekolah, Efektifitas Supervisi terhadap Motivasi Berprestasi, Disiplin Kerja dan Produktivitas Kerja SMA N 1 Yogyakarta, ( Jurnal e prints UMS Surakarta), 2016.
} 
Penelitian terkait supervise akademik kepala sekolah, disiplin kerja guru dan produktivitas kerja guru memang sudah banyak dilakukan, namun penelitian tersebut mayoritas dilakukan pada lembaga tingkat menengah ke atas, sedangkan penelitian yang dilakukan di tingkat sekolah dasar masih jarang dilakukan, oleh karena itu peneliti tertarik untuk melakukan penelitian tentang Pengaruh Supervisi Akademik Kepala Sekolah dan Disiplin Kerja Guru terhadap Produktivitas Kerja Guru Sekolah Dasar Negeri Se Kecamatan Mumbulsari Kabupaten Jember.

\section{B. Kajian Teori}

\section{Produktivitas Kerja Guru}

Pengertian produktivitas kerja dirumuskan oleh National Productivity Board (NPB) Singapore sebagaimana dikutip oleh Ahmad Susanto, produktivitas kerja diartikan sebagai sikap mental (attitude of mind) yang mempunyai semangat untuk melakukan peningkatan perbaikan.21 Produktivitas kerja guru dapat dilihat dari unjuk kerja dalam bidang tugasnya dan berbagai usaha untuk meningkatkan dan memperkaya kualitas akademik melalui berbagai kegiatan formal ataupun informal yang diselenggarakan oleh lembaga ataupun usaha pribadi.Wujud dari produktivitas di sini dapat berupa pelayanan yang baik dengan memperlihatkan kinerjanya. ${ }^{22}$

Adapun faktor-faktor yang mempengaruhi produktivitas kerja guru menurut Susanto antara lain: sikap kerja, tingkat ketrampilan, hubungan antara tenaga kerja dan pimpinan organisasi, dan manajemen produktivitas. $^{23}$ Pendapat lain dikemukakan oleh Sedarmayanti bahwa faktor yang mempengaruhi produktivitas kerja diantaranya adalah (1) sikap mental, berupa motivasi kerja, disiplin kerja, dan etika kerja;(2) pendidikan; (3) keterampilan; (4) manajemen; (5) tingkat penghasilan; (6) gizi dan kesehatan; (7) jaminan sosial; (8) lingkungan dan iklim kerja; (9) sarana produksi; (10) teknologi; (11) kesempatan berpretasi. ${ }^{24}$

Faktor-faktor yang mempengaruhi peningkatan produktivitas kerja guru sebagaimana telah disebutkan sebelumnya, secara langsung maupun

\footnotetext{
${ }^{21}$ Ahmad Susanto, Mananajemen Peningkatan Kinerja Guru, (Jakarta: Pranadamedia Group, 2016), hlm. 106

${ }^{22}$ Ahmad Susanto, Mananajemen Peningkatan Kinerja Guru, (Jakarta: Pranadamedia Group, 2016), hlm. 109.

${ }^{23}$ Ahmad Susanto, Mananajemen Peningkatan Kinerja Guru, (Jakarta: Pranadamedia Group, 2016), hlm. 110.

${ }^{24}$ Sedarmayanti, Sumber Daya Manusia dan Produktivitas Kerja, (Bandung: Mandar Maju, 2009), hlm. 72.
}

$272 \mid$ JURNAL LISAN AL-HAL 
tidak langsung jika dipenuhi akan menjadikan guru/pendidik sebagai tenaga yang produktif. Adapun ciri-ciri seorang pegawai yang produktif yaitu: $^{25}$ a) Lebih dari memenuhi kualifikasi pekerjaan, artinya produktivitas tinggi tidak mungkin tercapai jika kualifikasi pegawai rendah; b) Bermotivasi tinggi; c) Mempunyai orientasi pekerjaan yang positif; d) Dewasa; dan e) Dapat bergaul dengan efektif.

Dalam penelitian ini pengukuran produktivitas kerja guru didasarkan pada pendapat Ahmad Susanto dan PP No 74 tahun 2008, diantaranya: Perencanaan dan pelaksanaan pembelajaran, prestasi akademik, karya pengembangan profesi, keikutsertaan dalam forum ilmiah.

\section{Supervisi Akademik Kepala Sekolah}

Pengertian supervisi akademik dikemukakan oleh Glickman dan Daresh sebagaimana dikutip Dharma bahwa supervisi akademik adalah serangkaian kegiatan membantu guru (pendidik) mengembangkan kemampuannya mengelola proses pembelajaran demi pencapaian tujuan pembelajaran. Supervisi akademik tidak bisa terlepas dari penilaian unjuk kerja pendidik. ${ }^{26}$

Pengertian di atas menggambarkan ada tiga konsep pokok dalam supervisi akademik, diantaranya:

a. Supervisi pembelajaran harus secara langsung mempengaruhi dan mengembangkan perilaku guru dalam proses pembelajaran.

b. Perilaku supervisor dalam membantu guru mengembangkan kemampuannnya harus didesain secara ofisial, jelas kapan memulai dan kapan mengakhiri program pengembangan tersebut.

c. Tujuan akhir supervisi pembelajaran adalah agar guru semakin mampu memfasilitasi proses pembelajaran bagi para siswanya. ${ }^{27}$

Secara umum Glickman sebagaimana dikutip Priansa mengatakan bahwa tujuan supervisi akademik adalah membantu guru untuk mengembangkan kemampuannya dalam mencapai tujuan pembelajaran yang direncanakan bagi peserta didiknya. ${ }^{28}$

${ }^{25}$ A. Dale Timpe,1989,Seri Manajemen Sumber Daya Manusia: Produktivitas.Terjemahan oleh Dimas SamudraRum dan Soesanto Boediono, (Jakarta: PT Elex Media Komputindo, 1992), hlm. 111.

${ }^{26}$ Surya Dharma, Metode dan Teknik Supervisi, ( Jakarta: Ditendik Dirjen Peningkatan Mutu Pendidikan dan Tendik Depdiknas, 2008), hlm. 9

27Ibrahim Bafadal, Supervisi Pengajaran, (Jakarta: Bumi Aksara, 1992), hlm. 115.

28 Donni Junni dan Rismi Somad, Manajemen Supevisi \& Kepemimpinan Kepala Sekolah, (Bandung: Alfabeta, 2014), hlm. 108

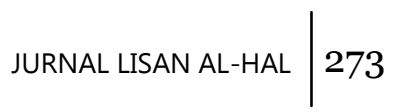


Sedangkan Sergiovanni sebagaimana dikutip Ahmad Susanto juga mengemukakan ada tiga tujuan supervisi akademik, yaitu: ${ }^{29}$

1) Supervisi akademik diselenggarakan dengan maksud membantu guru mengembangkan kemampuan profesonalnya dalam memahami akademik, kehidupan kelas, mengembangkan ketrampilan mengajarnya dan menggunakan kemampuannya melalui teknikteknik tertentu.

2) Supervisi akademik diselenggarakan dengan maksud untuk memonitor kegiatan proses belajar mengajar di sekolah.

3) Supervisi akademik diselenggarakan untuk mendorong guru menerapkan kemampuannya dalam melaksanakan tugas-tugas mengajarnya, mendorong guru mengembangkan kemampuannya sendiri, serta mendorong guru agar ia memiliki perhatian yang sungguh-sungguh terhadap tugas dan tanggung jawabnya.

Adapun supervisi akademik yang dilakukan oleh kepala sekolah dijelaskan dalam panduan Depdiknas sebagaimana dikutip oleh Priansa adalah sebagai berikut: ${ }^{30}$

1) Memahami konsep, prinsip, teori, teknologi, karakteristik, dan kecenderungan perkembangan/bimbingan tiap bidang pengembangan mata pelajaran di satuan pendidikan.

2) Membimbing guru dalam menyusun silabus tiap bidang pengembangan mata pelajaran di satuan pendidikan berlandaskan standar isi, standar kompetensi, dan kompetensi dasar, serta prinsipprnisip pengembangan KTSP.

3) Membimbing guru dalam memilih dan menggunakan strategi/metode/teknik pembelajaran.

4) Membimbing guru dalam menyusun RPP (Rencana Pelaksanaan Pembelajaran) untuk tiap bidang pengembangan mata pelajaran di satuan pendidikan.

5) Membimbing pendidik dalam melaksanakan kegiatan pembelajaran/bimbingan (di kelas, laboratorium, dan/atau di lapangan) untuk mengembangkan potensi peserta didik pada tiap bidang pengembangan mata pelajaran di satuan pendidikan.

${ }^{29} \mathrm{Ahmad}$ Susanto, Manajemen Peningkatan Kinerja Guru, (Jakarta: Prenadamedia Group, 2016), hlm. 220.

${ }^{30}$ Donni Juni Priansa dan Rismi Somad, Manajemen Supervisi \& Kepemimpinan Kepala Sekolah, (Bandung: Alfabeta, 2014), hlm. 116.

$274 \mid$ JURNAL LISAN AL-HAL 
6) Membimbing pendidik dalam mengelola, merawat, mengembangkan danmengunakan media pendidikan dan fasilitas pembelajaran/bimbingan.

7) Memotivasi pendidik untuk memanfaatkan teknologi informasi untuk pembelajaran/bimbingan.

Kunci keberhasilan supervisi akademik kepala sekolah dipengaruhi oleh banyak hal diantaranya lingkungan dimana sekolah berada, kondisi sosial ekonomi dan latar belakang pendidikan guru, serta kemampuan dan keahlian kepala sekolah itu sendiri dalam melakukan supervisi. Pengukuran supervisi akademik dalam penelitian ini didasarkan pada teori Glickman dan Sergiovanni yang terdiri dari: (1) Pengembangan profesionalisme guru dengan indikator: membantu guru menyusun silabus, membantu guru menyusun prota dan promes, membantu guru merencakan pengelolaan kelas, dan membantu guru mengembangkan ketrampilan mengajar; (2) Pengawasan berkualitas dengan indikator: melakukan kunjungan kelas, melakukan observasi dalam proses pembelajaran, melakukan percakapan pribadi dengan guru, dan melakukan pembinaan hasil observasi kelas; (3) Penumbuhan motivasi dengan indikator; (3) mendorong guru untuk melakukan pengembangan diri, dan mendorong guru agar memiliki komitmen terhadap tugas.

\section{Disiplin Kerja Guru}

Uno mengatakan bahwa disiplin merupakan suatu sikap mental seseorang, yang mencerminkan ketaatan terhadap aturan-aturan yang dilandasi oleh rasa tanggung jawab. ${ }^{31}$ Guru sebagai tenaga pendidik wajib mematuhi dan menaati seluruh peraturan yang berlaku. Peraturan dan tata tertib yang diterapkan oleh suatu instansi pendidikan khususnya sekolah sangat mengikat guru dalam kapasitas sebagai pegawai negeri sipil. Dengan demikian, disusunlah aturan-aturan yang berisi tentang berbagai pengalaman praktis, serta gagasan positif untuk menumbuhkan suasana kondusif bagi pengembangan kepribadian guru.

Selanjutnya Uno juga mengatakan bahwa disiplin kerja guru meliputi ketaatan dalam melaksanakan tugas pekerjaannya terutama dalam menaati dan melaksanakan tanggung jawabnya dalam bidang proses belajar mengajar dan pembinaan siswa. ${ }^{32}$ Dengan demikian disiplin

31 Hamzah B Uno \& Nina Lamatenggo, Tugas Guru dalam Pembelajaran, (Jakarta: Bumi Aksara, 2016), hlm. 36

${ }^{32}$ Hamzah B Uno \& Nina Lamatenggo, Tugas Guru dalam Pembelajaran, (Jakarta: Bumi Aksara, 2016), hlm. 39. 
kerja guru merupakan pengendalian perilaku yang disesuaikan dengan norma, kepatuhan, ketaatan, kesediaan, tanggung jawab dan kesadaran guru dalam bekerja berdasarkan peraturan dan kebijakan yang telah ditetapkan lembaga/instansi pendidikan yang bersangkutan.

Dari beberapa pengertian di atas dapat disimpulkan bahwa disiplin kerja merupakan upaya-upaya pengendalian perilaku seseorang (guru) dalam bekerja agar sesuai dengan peraturan-peraturan yang ditetapkan oleh suatu organisasi. Dalam hal ini sekolah bertujuan untuk membangun karakter dan kebiasaan kerja secara efisien dan efektif.

Adapun jenis disiplin menurut Uno dibedakan menurut tingkatannya, yaitu: ${ }^{33}$

1. Disiplin pribadi sebagai perwujudan yang lahir dari kepatuhan atas aturan-aturan yang mengatur perilaku individu;

2. Disiplin kelompok sebagai perwujudan disiplin yang lahir dari sikap taat dan patuh terhadap aturan hukum dan norma yang berlaku pada kelompok atau bidang-bidang kehidupan manusia.

3. Disiplin nasional, yaitu wujud disiplin yang lahir dari sikap patuh pada peraturan/undang-undang yang ditunjukkan kepada seluruh lapisan masyarakat secara nasional.

Dalam penelitian ini pengukuran disiplin kerja guru didasarkan pada teori yang disampaikan oleh Uno bahwa aspek-aspek pengukuran disiplin kerja guru terdiri dari: ${ }^{34}$ a) Pengendalian perilaku; b) Taat terhadap aturan; c) Kesediaan melakukan pekerjaan; d) Tanggung jawab melaksanakan tugas; dan e) Kesadaran atas tugas.

\section{Metode Penelitian}

Metode yang digunakan dalam penelitian ini metode penelitian kuantitatif dengan jenis penelitian survei yaitu pendekatan dasar yang dapat digunakan untuk mengetahui berbagai pola perilaku, pola sikap, pendapat dan opini responden. ${ }^{35}$

Sumber data berasal dari responden dan sesuai dengan hipotesis yang diajukan, maka data yang terkumpul diolah dan dianalisis menggunakan: (1) Statistik deskriptif untuk mengetahui karasteristik responden dan (2) Analisis regresi linier berganda untuk mengetahui

33 Hamzah B Uno \& Nina Lamatenggo, Tugas Guru dalam Pembelajaran, (Jakarta: Bumi Aksara, 2016), hlm. 16.

${ }^{34}$ Hamzah B Uno \& Nina Lamatenggo, Tugas Guru dalam Pembelajaran, (Jakarta: Bumi Aksara, 2016), hlm.41.

${ }^{35}$ Musfiqon, Metodologi Penelitian Pendidikan, (Jakarta: PT. Prestasi Pustakaraya, 2015), hlm. 67.

$276 \mid$ JURNAL LISAN AL-HAL 
apakah ada pengaruh Supervisi Akademik Kepala Sekolah dan Disiplin Kerja Guru terhadap Produktivitas Kerja Guru.

Penelitian ini dilaksanakan di Sekolah Dasar Negeri Se Kecamatan Mumbulsari Kabupaten Jember. Populasi dalam penelitian ini yaitu seluruh guru Pegawai Pegeri Sipil (PNS) yang bertugas di SD Negeri se Kecamatan Mumbulsari Kabpaten Jember yang berjumlah 148 orang guru. Untuk mendapatkan data yang lebih akurat maka dalam penelitian ini seluruh populasi menjadi subjek penelitian sehingga peneliti menggunakan teknik populasi sampling.

Variabel bebas dalam penelitian ini terdiri dari dua variabel yaitu Supervisi Akademik Kepala Sekolah $\left(\mathrm{X}_{1}\right)$, variabel Disiplin Kerja Guru $\left(\mathrm{X}_{2}\right)$, sedangkan variabel terikatnya Produktivitas Kerja Guru (Y).

Dalam penelitian ini data dikumpulkan menggunakan teknik survei. Teknik survei digunakan untuk mengetahui respon/pendapat responden tentang pelaksanaan supervisi akademik disiplin kerja guru, serta produktivitas kerja guru. Peneliti menyiapkan alat/instrumen penelitian berupa angket dan kemudian instrumen disebarkan kepada 148 responden yang tersebar di 21 SD Negeri Se Kecamatan Mumbulsari Kabupaten Jember, kemudian responden memberikan pendapat tentang kondisi terkait ketiga variabel tersebut di atas secara objektif. Setelah diisi maka kemudian angket dikembalikan kepada peneliti untuk diolah.

\section{Hasil Penelitian dan Pembahasan}

\section{Hasil Analisis Deskriptif}

Berdasarkan hasil prosentase tingkat pesetujuan responden terhadap variable supervise akademik kepala sekolah, disiplin kerja guru, dan produktivitas kerja guru maka dapat dijelaskan sebagai berikut: a) Dari 148 responden lebih dari 80\% menyatakan persetujuannya terhadap pentingnya supervise akademik yang dilakukan oleh kepala sekolah; b) Lebih dari $80 \%$ responden menyatakan persetujuannya terhadap pentingnya peningkatan kinerja guru; dan c) Lebih dari $80 \%$ responden menyatakan persetujuannya terhadap pentingnya peningkatan produktivitas kerja guru.

\section{Hasil pengujin Hipotesis}

\section{a. Pengaruh Supervisi Akademik Kepala Sekolah terhadap Produktivitas Kerja Guru}

Hipotesis dalam penelitian ini adalah pengaruh supervisi akademik kepala sekolah $\left(\mathrm{X}_{1}\right)$ terhadap produktivita kerja guru (Y). Pelaksanaan 
supervisi akademik yang baik akan meningkatkan produktivitas kerja guru.

Merujuk pada bab IV sub bab 3.b tentang hasil penelitian dengan uji t menunjukkan bahwa nilai signifikansi untuk variabel supervisi akademik kepala sekolah adalah 0,000 dan nilai tersebut lebih kecil dari 0,05. Selain itu hasil pengujian juga menunjukkan bahwa nilai koefisien $t\left(t_{h i t u n g}\right)$ yang diperoleh adalah 5,586. Sedangkan $t_{\text {tabel }}$ dengan $\alpha 5 \%$ dan jumlah responeden sebanyak 148 orang menunjukkan nilai 1,976. Hal ini berarti bahwa nilai signifikansi $0,000<0,05$ dan $t_{\text {hitung }}(5,586)>t_{\text {tabel }}(145: 0,05)$ $(1,976)$. Dengan demikian pengujian menunjukkan Ho ditolak dan $\mathrm{Ha}$ diterima. Dalam hal ini berarti supervisi akademik kepala sekolah berpengaruh terhadap produktivitas kerja guru.

Hasil pengujian persamaan regresi juga menyatakan bahwa pada pada setiap tindakan supervisi akademik kepala sekolah memberikan kontribusi sebesar 0,607 (60,7\%) untuk peningkatan produktivitas kerja guru. Sehingga dengan demikian dapat dsimpulkan semakin tinggi tingkat supervisi akademik yang dilakukan kepala sekolah maka semakin tinggi pula tingkat produktivitas kerja guru SD Negeri se kecamatan Mumbulsari Kabupaten Jember.

Hasil temuan menunjukkan bahwa supervisi akademik kepala berpengaruh terhadap peningkatan produktivitas kerja guru SD Neger se Kecamatan Mumbulsari. Secara teoritis supervisi akademik dapat mempengaruhi produktivitas kerja guru. Dalam penelitian ini kegiatan supervisi akademik kepala sekolah meliputi 3 hal, yaitu pengembangan profesionalisme guru, pengawasan kualitas, dan penumbuhan motivasi.

Fakta yang terjadi di lapangan menunjukkan bahwa supervisi akademik kepala sekolah yang meliputi pengembangan profesionalisme guru, pengawasan kualitas, dan penumbuhan motivasi memberi pengaruh secara positif dan dan signifikan terhadap poduktivitas kerja guru yang meliputi perencanaan dan pelaksanaan pembelajaran, prestasi akademik, karya pengembangan profesi dan keikutsertaan dalam forum ilmiah. Hal ini berarti hasil temuan penelitian ini mendukung/memperkuat hasil penelitian-penelitian sebelumnya. Sebagaimana penelitian yang dilakukan oleh Dimmera ${ }^{36}$, Widi Yuliani, ${ }^{37}$ Wahyudi, ${ }^{38}$ Sutama, ${ }^{39}$ menjelaskan bahwa

36 Bella Ghia Dimmera, Asrori, Wahyudi, Pengaruh Supervisi Akademik Kepala sekolah dan Kompetensi Profesional Guru terhadap Produktivitas kerja, (Jurnal Pendidikan dan pembelajaran, Vol. 5 No. 2), 2016.

${ }^{37}$ Widi Yuiani, Pengaruh Kualitas Kerja, Pengawasan Kerja dan Kedisiplinan terhadap Pduktivitas kerja, (Jurnal Ekonomi Volume 9 No. 2), 2011.

${ }^{38}$ Bella Ghia Dimmera, Asrori, Wahyudi, Pengaruh Supervisi Akademik Kepala

$278 \mid$ JURNAL LISAN AL-HAL 
supervisi akademik kepala sekolah berpengaruh signifikan terhadap produktivitas kerja guru. Dengan demikian dapat disimpulkan bahwa supervisi akademik kepala sekolah yang dilakukan secara intensif akan membantu guru meningkatkan produktivitas kerjanya sehingga akan terbentuklah guru yang kreatif dan produktif.

\section{b. Pengaruh Disiplin Kerja Guru terhadap Produktivitas Kerja Guru}

Rumusan hipotesis menyatakan ada pengaruh disiplin kerja guru $\left(\mathrm{X}_{2}\right)$ terhadap produktivitas kerja guru. Disiplin kerja guru yang tinggi akan meningkatkan produktivitas kerja guru. Adanya disiplin kerja guru yang tinggi terhadap semua peraturan/tata tertib yang telah ditentukan oleh lembaga maka diharapkan akan menumbuhkan tanggung jawab dalam melaksanakan tugas sehingga akan terwujud situasi pembelajaran yang kondusif.

Penelitian dengan uji t menunjukkan bahwa nilai signifikansi untuk variabel disiplin kerja guru adalah 0,000 dan nilai tersebut lebih kecil dari 0,05 . Selain itu hasil pengujian juga menunjukkan bahwa nilai koefisien $t$ ( $t_{\text {hitung) }}$ yang diperoleh adalah 5,708 . Sedangkan $t_{\text {tabel }}$ dengan $\alpha 5 \%$ dengan jumlah responden sebanyak 148 orang menunjukkan nilai 1,976. Hal ini berarti bahwa nilai signifikansi $0,000<0,05$ dan $t_{\text {hitung }}(5,708)>t_{\text {tabel }}$ $(145: 0,05)(1,976)$. Dengan demikian hasil pengujian menunjukkan Ho ditolak dan Ha diterima.

Begitu juga hasil persamaan regresi menyatakan bahwa setiap tindakan disiplin kerja guru memberikan kontribusi/pengaruh sebesar $0,426(42,6 \%)$ terhadap peningkatan produktivitas kerja guru. Hal ini berarti semakin tinggi disiplin kerja guru maka semakin tinggi pula tingkat produktivitas kerja guru SD Negeri se Kecamatan Mumbulsari Kabupaten Jember.

Hasil temuan menunjukkan bahwa disiplin ternyata berpengaruh signifikan terhadap produktivitas kerja guru SD Negeri se Kecamatan Mumbulsari Kabupaten Jember. Hasil temuan penelitian ini sesuai dengan teori-teori yang telah dikemukakan pada uraian sebelumnya. Artinya secara teoritis disiplin kerja guru mampu meningkatkan produktivitas kerja guru.

sekolah dan Kompetensi Profesional Guru terhadap Produktivitas kerja, Uurnal Pendidikan dan pembelajaran, Vol. 5 No. 2), 2016.

${ }^{39}$ Prof Sutama, Keson, Bajur, Peran Kompetensi Kepala Sekolah, Efektifitas Supervisi terhadap Motivasi Berprestasi, Disiplin Kerja dan Produktivitas Kerja SMA N 1 Yogyakarta, ( Jurnal e prints UMS Surakarta), 2016. 
Heru Widodo dalam penelitiannya mengatakan bahwa produktivitas kerja guru sangat dipengaruhi oleh disiplin. Disiplin sangat penting untuk pertumbuhan organisasi, bermanfaat mendidik guru untuk mematuhi dan menyenangi peraturan, prosedur, maupun kebijakan yang ada, sehingga dapat menghasilkan produktivitas kerja yang baik. ${ }^{40}$

Fakta yang terjadi di lapangan juga menunjukkan bahwa disiplin kerja yang meliputi pengendalian perilaku, kesetiaan/patuh pada peraturan, kesediaan melakukan pekerjaan, tanggung jawab melaksanakan tugas, dan kesadaran akan tugas memberi pengaruh secara positif terhadap produktivitas kerja guru yang meliputi perencanaan dan pelaksanaan pembelajaran, prestasi akademik, karya pengembangan profesi dan keikutsertaan dalam forum ilmiah. Hal ini berarti hasil temuan penelitian ini sesuai dan mendukung hasil penelitian sebelumnya.

\section{c. Pengaruh Supervisi Akademik Kepala Sekolah dan Disiplin Kerja Guru terhadap Produktivitas Kerja Guru}

Hipotesis yang ketiga yang diteliti kebenaranya dalam penelitian ini adalah ada pengaruh supervisi akademik kepala sekolah $\left(\mathrm{X}_{1}\right)$ dan disiplin kerja guru $\left(\mathrm{X}_{2}\right)$ terhadap produktivitas kerja guru (Y). Semakin tinggi tingkat supervisi akademik kepala sekolah dan disiplin kerja guru, maka akan semakin meningkat pula produktivitas kerja guru.

Dalam penelitian ini yang dimaksud produktivitas kerja guru adalah hasil kerja guru dalam melaksanakan tugasnya, baik dalam bidang pengajarandan rasa tanggung jawab untuk memperoleh hasil terbaik dan berbagai usaha dalam peningkatan kualitas akademik diantaranya melakukan penelitian, menulis artikel, dan membuat media pembelajaran dalam proses pembelajaran.

Hasil uji simultan(uji F) menunjukkan bahwa nilai koefisien Fhitung ( $F_{\text {hitung }}$ ) yang diperoleh adalah 38,93. Adapun $F_{\text {tabel }}$ dengan nilai $\alpha 5 \%$ dan jumlah responden sebanyak 148 orang menunjukkan nilai 3,058. Selain itu nilai signifikansi uji F diperoleh nilai 0,000. Nilai signifikansi ini lebih kecil dari probabilitas alpha yang ditetapkan yaitu 0,05 (sig. F < probabilitas $\alpha$ ). Dari hasil tersebut menunjukkan bahwa besaran probabilitas (sig) 0,000 < 0,05 dan $F_{\text {hitung }}(38,93)>F_{\text {tabel }}(2: 145: 0,05) \quad(3,058)$. Dengan demikian pengujian menunjukkan Ho ditolah dan Ha diterima.

Hasil persamaan regresi juga menyatakan bahwa pada dasarnya variabel produktivitas kerja guru sudah berpotensi sebesar 7,356\% tanpa

\footnotetext{
${ }^{40}$ Heru Widodo, Pengaruh Kompetensi Profesional, Lingkungan Kerja, Disiplin dan Diklat terhadap Produktivitas Guru, (e-jurnal STIE-AUB), 2016.
} 
dipengaruhi oleh faktor apapun. Dalam artian bahwa guru SD Negeri se Kecamatan Mumbulsari Kabupaten Jember memiliki tingkat produktivitas sebesar 7,35\% sebelum atau tanpa dipengaruhi oleh tindakan supervisi akademik kepala sekolah maupun disiplin kerja guru itu sendiri. Untuk selanjutnya setiap tindakan supervisi akademik kepala sekolah memberikan kontribusi sebesar 0,607 (60,7\%) dan setiap tindakan disiplin kerja memberikan kontribusi sebesar 0,426 (42,6\%) terhadap perubahan/peningkatan produktivitas kerja guru. Hal ini menunjukkan bahwa semakin tinggi tingkat supervisi akademik kepala sekolah dan dibarengi dengan peningkatan disiplin guru maka akan berpengaruh terhadap peningkatan produktivitas kerja guru SD Negeri se Kecamatan Mumbulsari Kabupaten Jember.

Dari hasil analisis korelasi menunjukkan bahwa pengaruh variabel supervisi akademik kepala sekolah dan disiplin kerja guru terhadap produktivitas kerja guru diperoleh nilai $\mathrm{R}$ sebesar 0,591 . Hal ini berarti bahwa sebesar $59,1 \%$ perubahan variabel produktivitas kerja guru dipengaruhi/disebabkan oleh perubahan variabel supervisi akademik kepala sekolah $\left(\mathrm{X}_{1}\right)$ dan variabel disiplin kerja guru $\left(\mathrm{X}_{2}\right)$, sedangkan selebihnya sebesar 40,9\% dipengaruhi oleh faktor lain selain supervisi akademik kepala sekolah dan disiplin kerja guru.

Dalam hal ini dapat dikatakan bahwa hasil penelitian ini menjawab hipotesis yang ketiga yang menyebutkan supervisi akademik kepala sekolah dan disiplin kerja guru berpengaruh positif terhadap produktivitas kerja guru. Dengan demikian dapat disimpulkan bahwa supervisi akademik kepala sekolah dan disiplin kerja guru secara simultan berpengaruh positif dan signifikan terhadap produktivitas kerja guru SD Negeri se Kecamatan Mumbulsari Kabupaten Jember.

\section{E. Simpulan}

Terdapat pengaruh positif dan signifikan antara supervisi akademik kepala sekolah terhadap produktivitas kerja guru SD Negeri se Kecamatan Mumbulsari Kabupaten Jember. Semakin tinggi supervisi akademik kepala sekolah maka akan semakin meningkat pula produktivitas kerja guru SD Negeri se Kecamatan Mumbulsari Kabupaten Jember.

Selain itu juga terdapat pengaruh positif dan signifikan antara disiplin kerja guru terhadap produktivitas kerja guru SD Negeri se Kecamatan Mumbulsari Kabupaten Jember. Semakin tinggi tingkat disiplin kerja guru maka akan semakin meningkat pula pula produktivitas kerja guru SD Negeri se Kecamatan Mumbulsari Kabupaten Jember. 
Ditemukan juga pengaruh positif dan signifikan secara simultan supervisi akademik kepala sekolah dan disiplin kerja guru terhadap produktivitas kerja guru SD Negeri se Kecamatan Mumbulsari Kabupaten Jember sebesar 59,1\%, sedangkan sebanyak 40,9\% dipengaruhi oleh faktor lain selain supervisi akademik akademik kepala sekolah dan disiplin kerja guru.

\section{DAFTAR PUSTAKA}

Mulyasa. Uji Kompetensi dan Penilaian Kinerja Guru. Bandung: PT Remaja Rosdakarya, 2013.

UNDP, Laporan Peringkat HDI Indonesia terbaru 2016, http//www.kompasiana.com, 21 Maret 2017, diakses tanggal 5 Mei 2017.

Aqib, Zainal. Profesionalisme Guru dalam Pembelajaran.Surabaya: Insan Cendekia, 2010.

Suparlan. Guru Sebagai Profes. Yogyakarta: Hikayat Publishing, 2006.

Tri Atmadji Sutikno. Indikator Produktivitas Kerja Gurun Sekolah Menengah Kejujuran, VOL. 32, NO. 1, Februari 2009: 107-118

Sinungan. Produktivitas Apa dan Bagaimana. Jakarta: Bumi Aksara, 2009.

Susanto, Ahmad. Manajemen Peningkatan Kinerja Guru. Jakarta: Prenadamedia Group, 2016.

Dwi Agung Nugroho Arianto, Analisis Penyebab Dampak Rendahnya Semangat Kerja Guru, Jurnal Dinamika Ekonomi dan Bisnis, Vol 11 No. 1 Maret 2014.

Sedarmayanti, Sumber Daya Manusia dan Produktivitas Kerja, Bandung: Mandar Maju, 2009.

Susanto, Ahmad. Manajemen Peningkatan Kinerja Guru. Jakarta: Prenadamedia Group, 2016.

Sutrisno, Edy. ManajemenSumberdayaManusia. Jakarta: Prenamedia Group, 2016.

Widodo, Heru. Pengaruh Kompetensi Profesional, Lingkungan Kerja, Disiplin dan Diklat terhadap Produktivitas Guru, (e-jurnal STIE-AUB), 2016.

Utami, Sri. Hubungan antara Lingkungan Kerja dan Disiplin Kerja dengan produktivitas kerja Guru SMP Negeri Tenggarong. (E-Jurnal Unikarta Cemerlang), 2009.

Sri Sugiarti, Alwi Suddin, Ernawati, Pengaruh Kepemimpinan, Disiplin dan Kompetensi terhadap Poduktivitas Kerja Guru dengan Loyalitas sebagai variabel Media pada SMP Negeri 4 Surakarta, (e-jurnal Unisri,

$282 \mid$ JURNAL LISAN AL-HAL 
Vol. 10 No. 1), 2016.

Heri Prihatin, Heri. Pengaruh Tingkat Pendidikan Guru dan kedisiplinan Kerja terhadap produktivitas Kerja Guru MTs Negeri Nguntoronadi Kabupaten Wonogiri, Tesis IAIN Surakarta, 2014.

Sagala, Saiful. Supervisi Pembelajaran. Bandung: Alfabeta, 2010.

I Wayan arnasa, Nyoman Natajaya, I Gusti Ketut Arya Sunu, Kontribusi Kompetensi Guru, Etos Kerja Guru, Budaya Organisasi, dan Supervisi terhadap Produktivitas Kerja Guru di Sekolah Regant School Denpasar, Uurnal Program Sarjana Universitas Pendidikan Ganesha, Volume 5), 2014.

Yuliani, Widi. Pengaruh Kualitas Kerja, Pengawasan Kerja dan Kedisiplinan terhadap Pduktivitas kerja, (Jurnal Ekonomi Volume 9 No. 2), 2011.

Bella Ghia Dimmera, Asrori, Wahyudi, Pengaruh Supervisi Akademik Kepala sekolah dan Kompetensi Profesional Guru terhadap Produktivitas kerja, Uurnal Pendidikan dan pembelajaran, Vol. 5 No. 2), 2016.

Prof Sutama, Keson, Bajur, Peran Kompetensi Kepala Sekolah, Efektifitas Supervisi terhadap Motivasi Berprestasi, Disiplin Kerja dan Produktivitas Kerja SMA N 1 Yogyakarta, ( Jurnal e prints UMS Surakarta), 2016.

Sedarmayanti, Sumber Daya Manusia dan Produktivitas Kerja, Bandung: Mandar Maju, 2009.

Timpe, Dale. 1989. Seri Manajemen Sumber Daya Manusia: Produktivitas.Terjemahan oleh Dimas SamudraRum dan Soesanto Boediono, Jakarta: PT Elex Media Komputindo, 1992.

Bafadal, Ibrahim. Supervisi Pengajaran, Jakarta: Bumi Aksara, 1992.

Junni, Donni dan Rismi Somad. Manajemen Supevisi \& Kepemimpinan Kepala Sekolah, Bandung: Alfabeta, 2014.

B Uno, Hamzah \& Nina Lamatenggo, Tugas Guru dalam Pembelajaran, Jakarta: Bumi Aksara, 2016.

P. Siagian, Sondang. Manajemen Sumber Daya Manusia, Jakarta: Bumi Aksara, 2011.

Musfiqon, Metodologi Penelitian Pendidikan, Jakarta: PT. Prestasi Pustakaraya, 2015. 
"Supervisi Akademik Kepala Sekolah"

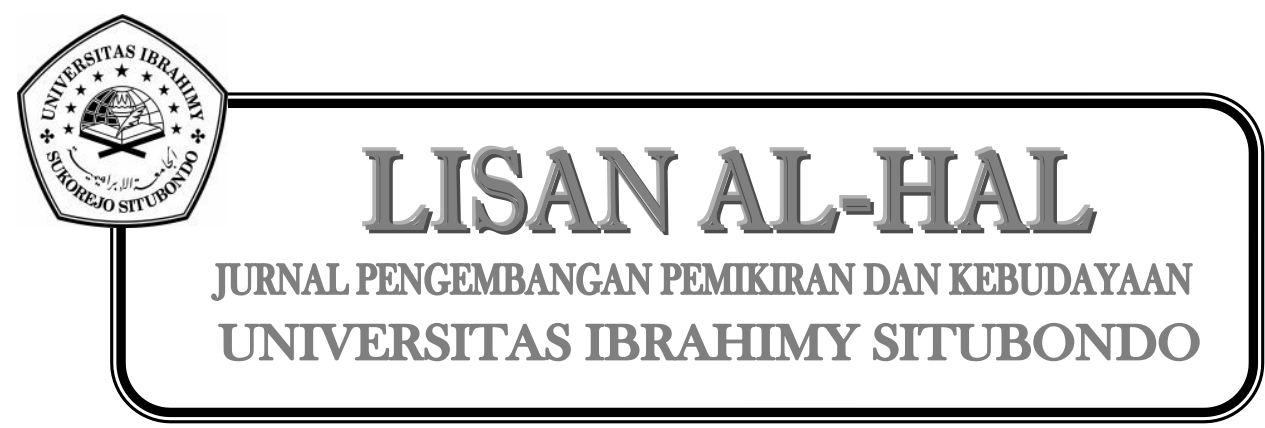

284 JURNAL LISAN AL-HAL 